\title{
Familial Chylomicronemia (Type I Hyperlipoproteinemia) Due to a Single Missense Mutation in the Lipoprotein Lipase Gene
}

\author{
Detlev Ameis," Junji Kobayashi," Richard C. Davis, " Osnat Ben-Zeev," Mary J. Malloy,” \\ John P. Kane," Gregory Lee, * Howard Wong," Richard J. Havel, ${ }^{*}$ and Michael C. Schotz \\ *Veterans Administration Wadsworth Medical Center, Los Angeles, California 90073, and Department of Medicine, \\ University of California, Los Angeles, California 90024; and ${ }^{\ddagger}$ Cardiovascular Research Institute, \\ and Departments of Pediatrics and Medicine, University of California, San Francisco, California 94143
}

\begin{abstract}
Complete deficiency of lipoprotein lipase (LPL) causes the chylomicronemia syndrome. To understand the molecular basis of LPL deficiency, two siblings with drastically reduced postheparin plasma lipolytic activities were selected for analysis of their LPL gene. We used the polymerase chain reaction to examine the nine coding LPL exons in the two affected siblings and three relatives. DNA sequence analysis revealed a single nucleotide change compared with the normal LPL cDNA: a $G \rightarrow$ A substitution at nucleotide position 680 . This transition caused a replacement of glutamic acid for glycine at amino acid residue 142 of the mature LPL protein. Amino acid sequence comparisons of the region surrounding glycine-142 indicated that it is highly conserved among lipases from different species, suggesting a crucial role of this domain for the LPL structure. Expression studies of the mutant LPL cDNA in COS-7 cells produced normal amounts of enzyme mass. However, the mutated LPL was not catalytically active, nor was it efficiently secreted from the cells. This established that the Gly $\rightarrow$ Glu substitution at amino acid 142 is sufficient to abolish enzymatic activity and to result in the chylomicronemia syndrome observed in these patients. (J. Clin. Invest. 1991.87:1165-1170.) Key words: polymerase chain reaction • triglyceride
\end{abstract}

\section{Introduction}

Familial chylomicronemia (type I hyperlipoproteinemia) is a rare disorder of lipid metabolism characterized by a massive increase in chylomicron levels in fasting plasma and a marked increase in plasma triglyceride levels (1). This metabolic alteration is associated with a variety of clinical features, including recurrent abdominal pain, pancreatitis, hepatosplenomegaly, eruptive cutaneous xanthomas, and retinal lipemia (1). Two variants, deficiencies of lipoprotein lipase (LPL) ${ }^{1}(2)$ and of apolipoprotein C-II (3), have been identified as causes of this

Address correspondence to Dr. Michael C. Schotz, VA Wadsworth Medical Center, Building 113, Room 312, Los Angeles, CA 90073.

Dr. Ameis's present address is I. Medizinische Klinik, UniversitätsKrankenhaus Eppendorf, D-2000 Hamburg 20, FRG. Dr. Kobayashi's present address is Medical Department, Chiba University, Chiba, Japan.

Received for publication 2 August 1990 and in revised form 5 October 1990.

1. Abbreviations used in this paper: LPL, lipoprotein lipase; PCR, polymerase chain reaction.

The Journal of Clinical Investigation, Inc.

Volume 87, April 1991, 1165-1170 disease. A rarer disorder, transmitted as an autosomal dominant trait, results from the presence of a circulating inhibitor of LPL (4). In addition, an autoimmune mechanism has been proposed in a recently reported case of chylomicronemia (5).

LPL, the hydrolytic enzyme involved in a majority of cases with familial chylomicronemia, plays a pivotal role in the metabolism of plasma lipoproteins $(6,7)$. This enzyme is synthesized by the parenchymal cells of many tissues, most notably adipose tissue, heart and muscle, and is transported to the luminal surface of vascular endothelial cells, where it presumably binds to heparan sulfate $(8,9)$. At this site, LPL is rate-limiting for the hydrolysis and removal of triglycerides associated with chylomicrons and very low density lipoproteins (VLDL). Intravenous heparin releases LPL into the blood where its enzymatic activity $(10,11)$ and its mass $(12,13)$ can be assayed. The absence or near absence of LPL activity in postheparin plasma establishes the diagnosis of LPL deficiency.

Functional LPL is a homodimeric glycoprotein with a subunit of 448 amino acids (14). The LPL gene has been mapped to the short arm of human chromosome 8 (15) and recent genomic cloning has shown it to be composed of 10 exons spanning $\sim 30 \mathrm{~kb}(16,17)$. Genomic and cDNA sequence comparisons have localized a region on exons 4 and 5 demonstrating a remarkably high degree of homology to other lipases (1828 ) and a significant homology to serine proteases (29) and Drosophila yolk proteins (30). The availability of these human LPL clones and genomic sequence information has made possible two diagnostic approaches to assess directly the molecular basis of LPL deficiency. First, transmission of LPL mutations in families can be traced using restriction fragment length polymorphisms (RFLP). Recent studies utilizing this technique identified gross alterations in the LPL gene responsible for primary LPL deficiency in a significant number of type I hyperlipoproteinemias $(31,32)$. An alternative and more sensitive approach, based on DNA sequence analysis, involves the direct identification of the deficiency-causing mutation in the LPL gene. Two recent studies have employed this technique to characterize the genetic defect of LPL-deficient individuals, both demonstrating a catalytically inactive enzyme and some impaired binding to heparin $(33,34)$.

In this report, we searched for point mutations affecting the structural gene for LPL in two type I hyperlipoproteinemic siblings from a family of Northern European descent. The genomic sequence obtained revealed a single-base change in these individuals resulting in a substitution of glutamic acid for glycine at amino acid residue 142. This substitution occurs within a region of the LPL gene that is highly conserved among lipases from different species, suggesting that this region is essential for functional activity of these enzymes. Introduction of this mutation into the normal LPL cDNA and cellular expression stud- 
ies confirm that substitution of glutamic acid for glycine 142 is sufficient to virtually abolish enzymatic activity. Thus, this phenotype is consistent with the enzymatic deficiency in the type I hyperlipoproteinemic subjects described in this report.

\section{Methods}

Subjects. We studied five members of a family of northern European ancestry with LPL deficiency (Table I). The proband, age 22, whose parents are first cousins and had received genetic counseling, was $3.5 \mathrm{~kg}$ at birth after a normal gestation period and was delivered at $42 \mathrm{wk}$. At age $27 \mathrm{~d}$ he had an episode of melena with normal upper GI series. The bleeding ceased after vitamin $\mathrm{K}$ treatment. Plasma triglyceride levels were $337 \mathrm{mmol} / \mathrm{liter}(30,000 \mathrm{mg} / \mathrm{dl})$. The infant had lipemia retinalis and several eruptive xanthomas and no hepatosplenomegaly. On a fatfree formula, the serum triglycerides were $25.3 \mathrm{mmol} / \mathrm{liter}(2,250 \mathrm{mg} /$ dl) and $9.5 \mathrm{mmol} / \mathrm{liter}(844 \mathrm{mg} / \mathrm{dl})$ by the 10 th and 15 th day, respectively. The proband has continued to eat a moderately low-fat diet and has maintained serum triglycerides below $11.2 \mathrm{mmol} / \mathrm{liter}(1,000 \mathrm{mg} /$ dl). Occasionally, xanthomas have recurred but he has had no abdominal pain or overt pancreatitis. His apolipoprotein E phenotype is E4/2 (35). The appearance of his apolipoprotein C-II band is normal on isoelectric focusing (36). A female sibling developed at 3 mo generalized eruptive xanthomas and had an episode of melena. Over the past 25 years she has had a history of recurrent abdominal discomfort, two episodes of acute pancreatitis, and recurrent eruptive xanthomas. She has frequently had triglyceride levels in the range of $22.5 \mathrm{mmol} /$ liter $(2,000 \mathrm{mg} / \mathrm{dl}) ;$ neither the liver nor the spleen have been enlarged. The second episode of pancreatitis occurred during the third month of her pregnancy. With a calorie- and fat-controlled diet, she had no further problems and delivered a normal infant. Her apolipoprotein C-II band appeared normal on isoelectric focusing; her apolipoprotein $\mathrm{E}$ phenotype is $\mathrm{E} 2 / 2$.

Preparation of DNA and oligonucleotide primers. DNA was extracted either from peripheral-blood mononuclear cells or from Epstein-Barr-virus-transformed lymphoblastoid cell lines $(37,38)$. Buffycoat leukocytes were isolated from blood collected into tubes containing EDTA (Vacutainer, Becton Dickinson, Rutherford, NJ). Chromosomal DNA was released by lysis of cells in $10 \mathrm{mM}$ Tris- $\mathrm{HCl}$, pH $8.0,150 \mathrm{mM} \mathrm{NaCl}, 1.5 \mathrm{mM} \mathrm{MgCl}_{2}, 0.5 \%$ Triton X-100, and $1 \%$ SDS containing $500 \mu \mathrm{g} / \mathrm{ml}$ of proteinase K (Merck, Darmstadt, FRG). The lysates were incubated for $16 \mathrm{~h}$ at $37^{\circ} \mathrm{C}$ with gentle agitation. After extraction with phenol and chloroform, DNA was recovered by eth- anol precipitation. DNA was dissolved at $37^{\circ} \mathrm{C}$ for $2 \mathrm{~h}$ before spectrophotometric quantitation. Oligonucleotide primers were synthesized on an model 381A synthesizer (Applied Biosystems, Inc., Foster City, CA) using the $\beta$-cyanoethyl phosphoraramidite method, and were purified by reverse-phase chromatography cartridges (OPC, Applied Biosystems, Inc.). The polymerase chain reaction (PCR) primers were constructed complementary to DNA sequences flanking exons 1-9 of the LPL gene (17).

PCR amplification and direct sequence determination of amplified $D N A$. Target sequences were amplified (39) in a $100-\mu 1$ reaction volume containing $0.5 \mu \mathrm{g}$ of chromosomal DNA; $50 \mathrm{pmol}$ of each oligonucleotide primer; $200 \mu \mathrm{M}$ of each dATP, dCTP, dGTP, and dTTP; $1 \times$ reaction buffer $\left(50 \mathrm{mM} \mathrm{KCl}, 10 \mathrm{mM}\right.$ Tris- $\mathrm{HCl}, \mathrm{pH} 8.4,3 \mathrm{mM} \mathrm{MgCl}_{2}$, $0.05 \%$ polysorbate (Tween) $20,0.05 \%$ Triton X-100 (40), $200 \mu \mathrm{g} / \mathrm{ml}$ of gelatin); and $2 \mathrm{U}$ of Taq DNA polymerase (Stratagene, Inc., San Diego, CA). 30 cycles of PCR amplification were performed on a thermocycler (Ericomp, San Diego, CA). Each cycle consisted of 1 min denaturation at $94^{\circ} \mathrm{C}, 1 \mathrm{~min}$ at $55^{\circ} \mathrm{C}$ to anneal the oligonucleotide primers to their target sequences, and $2 \mathrm{~min}$ at $72^{\circ} \mathrm{C}$ for chain elongation. Amplified DNA was desalted and excess oligonucleotide primers and deoxynucleotide triphosphates removed by spin-dialysis on a Centricon-30 microconcentrator (Amicon Corp., Danvers, MA) or by electroelution using $1 \%$ agarose gels. The PCR products were resolved by electrophoresis on $1.4 \%$ SeaKem agarose gels (FMC Corp., Marine Colloids Division, Rockland, IL) in Tris-borate buffer containing $0.5 \mu \mathrm{g} / \mathrm{ml}$ of ethidium bromide (41). Sequence analysis was performed with gel-purified PCR products using the dideoxy-chain termination method (42). 50\% of the amplification product was denatured using $2 \mathrm{~N} \mathrm{NaOH}$ at room temperature for $10 \mathrm{~min}$. The DNA was precipitated with ethanol and the resuspended product was annealed to 1 pmol of oligonucleotide primer for $20 \mathrm{~min}$ at $37^{\circ} \mathrm{C}$. DNA was sequenced using [ $\alpha^{35}$-S]dATP $(600 \mathrm{Ci} / \mathrm{mmol}$; Amersham Corp., Arlington Heights, IL) and T7 DNA polymerase (United States Biochemical Corp., Cleveland, $\mathrm{OH}$ ). Sequencing reaction mixtures were subjected to electrophoresis on $6 \%$ acrylamide gels containing $8 \mathrm{M}$ urea. Gels were exposed to Kodak XAR film for $48 \mathrm{~h}$.

Site-directed mutagenesis and expression. The human cDNA clone for LPL was directionally transferred to the Sal I/Eco RI site of Phagescript (Stratagene, Inc.), an M-13-based bacteriophage. Oligonucleotide-directed mutagenesis was performed using materials and instructions from Amersham Corp. The mutant oligonucleotide consisted of 21 bases corresponding to codons $139-145$ of normal human LPL except for the middle $G$ residue in codon 142 which was changed to $A$,

Table I. Lipid and Lipoprotein Contentrations, LPL Activity, and Mass in the LPL-deficient Kindred

\begin{tabular}{|c|c|c|c|c|c|}
\hline & \multicolumn{5}{|c|}{ Subject/age $(y r)$} \\
\hline & Proband/22 & Sibling/26 & Father/49 & Mother/49 & $\begin{array}{c}\text { Paternal } \\
\text { grandfather/75 }\end{array}$ \\
\hline \multicolumn{6}{|l|}{ Triglycerides* } \\
\hline Total & $12.3(1094)$ & $12.5(1113)$ & $1.36(121)$ & $0.91(81)$ & $0.63(56)$ \\
\hline VLDL & $10.7(953)$ & $11.2(998)$ & & & \\
\hline LDL & $0.28(25)$ & $0.28(25)$ & & & \\
\hline HDL & $0.22(20)$ & $0.44(39)$ & & & \\
\hline \multicolumn{6}{|l|}{ Cholesterol* } \\
\hline Total & $3.3(127)$ & $6.7(257)$ & $4.2(162)$ & $4.3(165)$ & $3.4(132)$ \\
\hline VLDL & $2.3(89)$ & $5.2(202)$ & & & \\
\hline LDL & $0.54(21)$ & $0.73(28)$ & & & \\
\hline HDL & $0.21(8)$ & $0.34(13)$ & & & \\
\hline LPL activity ${ }^{\ddagger}$ & 15 & 39 & & & \\
\hline LPL mass ${ }^{8}$ & 40 & & & & \\
\hline
\end{tabular}

${ }^{*}$ In mmol/l (mg/dl). ${ }^{\ddagger} \mathrm{LPL}$ activity in $\mathrm{nmol} / \mathrm{ml} / \mathrm{min}$; control $(n=4) 180 \pm 45 .{ }^{8} \mathrm{LPL}$ mass in $\mathrm{ng} / \mathrm{ml}$; control $(n=8) 602 \pm 277$. 
resulting in a triplet encoding for glutamic acid rather than glycine (5 GGC ATT GCA GAA AGT CTG ACC $3^{\prime}$ ). After verification of the sequence (42), the mutant cDNA was transferred to the Xho I/Bam HI site of the plasmid expression vector pSVL (Pharmacia Fine Chemicals, Piscataway, NJ). The entire mutant clone was subsequently sequenced to verify the presence of the desired mutation and the absence of other sequence alterations. COS-7 cells were transfected with normal or mutant LPL in pSVL using lipofection as indicated by the supplier (Bethesda Research Laboratories, Gaithersburg, MD). $48 \mathrm{~h}$ after DNA transfection, the cell medium was supplemented with heparin $(5 \mathrm{U} /$ $\mathrm{ml}$ ). After an additional $18 \mathrm{~h}$, culture media and cell extracts from three 60-mm plates were pooled and assayed for LPL activity and mass.

Lipoprotein lipase assays. LPL activity was assayed using synthetic triacylglycerol substrates $(10,43) .1 \mathrm{mU}$ of enzyme activity represents the release of $1 \mathrm{nmol}$ of free fatty acid per min. Enzyme mass was determined by a previously described enzyme-linked immunosorbent assay (12).

\section{Results}

To determine the molecular defect in familial chylomicronemia, we assessed the structure of the LPL gene in the two siblings with primary LPL deficiency (Table I). The enzyme deficiency was diagnosed by the greatly reduced postheparin plasma LPL activity. The structure of the complete LPL gene was investigated using Southern blot analysis with ${ }^{32} \mathrm{P}$-labeled LPL cDNA probes (LPL 35, 37, and 46; reference 14). No major alteration of the LPL gene was detected in the two LPLdeficient patients (data not shown). The LPL gene was then examined in detail, using the PCR technique (39) and doublestranded DNA sequence analysis (41). To amplify LPL exons, we synthesized a pair of oligonucleotide primers specific for each exon. These primers were complementary to intron sequences flanking the individual exons, as illustrated for exon 4 in Fig. 1. Additional primers were used to perform DNA sequence analysis. Using this approach, the nine coding exons of LPL were amplified and sequenced. When compared to a control subject and to the LPL cDNA sequence (14), a single base change was observed in exon 4 in the two LPL-deficient subjects (Fig. 2). The detected single base mutation, a G-to-A tran- sition at nucleotide position 680 , results in replacement of a glycine (GGA) by a glutamic acid (GAA) at amino acid position 142. This finding was verified by determining the gene sequence for the complementary strands. To trace the inheritance of the observed mutation, three key members of the affected family, the father, the mother, and the paternal grandfather were analyzed. DNA sequence determination for these three family members demonstrated heterozygosity for the observed mutation (Fig. 2).

To assess whether the observed amino acid substitution could be responsible for the decrease in enzymatic activity, we compared the primary structure from four mammalian species (human, cow, mouse, guinea pig) and one avian species (chicken) in the region surrounding the mutation (Fig. 3). Within the highly conserved domain between glycine-130 and threonine-145, only two interspecies polymorphisms exist; isoleucine-140 in the human LPL is replaced with valine in the murine and cavian enzymes. In addition, leucine-144 in the human LPL is replaced with arginine in the cavian enzyme. Strikingly, glycine-142, the site of the observed mutation in the human LPL-deficient patients, is conserved in all five species of LPL (Fig. 3), as well as in other lipase family members (not shown). These data suggest that this conserved amino acid is required for normal lipolytic function.

To determine whether the substitution of glutamic acid for glycine observed in the LPL-deficient kindred could be responsible for the absence of enzymatic activity, we used sitedirected mutagenesis to introduce that mutation into normal LPL cDNA. Expression studies in COS-7 cells produced a mutated lipase that had little detectable hydrolytic activity when compared with the expression of native LPL (Fig. $4 A$ ). However, LPL mass determinations indicate that the mutant lipase is present intracellularly to at least the same levels as the controls (Fig. 4 B). Further, the mutant lipase mass was drastically reduced in the media of these cells, suggesting decreased secretion of the mutant protein (Fig. $4 \mathrm{~B}$ ). Interestingly, LPL mass determination in the LPL-deficient proband demonstrated a low but measurable enzyme mass of $40 \mathrm{ng} / \mathrm{ml}$ of post-heparin plasma (Table I). Thus, as a model for this particular LPL-defi-
A

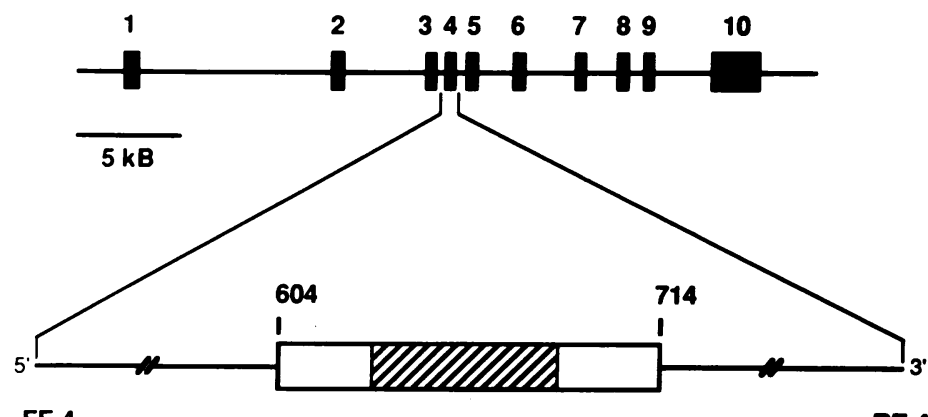

FSE $4 \rightarrow$

$<$ RSE 4

Figure 1. Schematic representation of the human lipoprotein lipase gene and amplification strategy for exon 4. (A) Solid boxes indicate the position of exons 1-10 of the LPL gene (17). The region containing exon 4 of the LPL gene (Glu 117-Thr 153) is indicated by the box in $B$. The core of this exon (Val 126-Ser 143) is highly conserved between LPL, hepatic lipase, and pancreatic lipase from a variety of species (20-28). This region is demarcated by hatched lines. Horizontal lines on either end of the exon box denote flanking intron sequences. The exon-intron boundaries are indicated by numbers 604 and 714 , referring to their nucleotide position on the human LPL cDNA (14). The segment chosen for PCR amplification is shown by the binding-sites for oligonucleotide primers FE 4 and RE 4 whose $5^{\prime}$ to $3^{\prime}$ orientation is indicated by arrows. The length of the PCR-amplified region, a 416-bp DNA fragment, is represented by a dotted line. $(C)$ DNA sequences of the oligonucleotide primers used in the polymerase chain reaction assay (FE4 and RE4) and in the subsequent DNA sequencing (FSE4 and RSE4). 


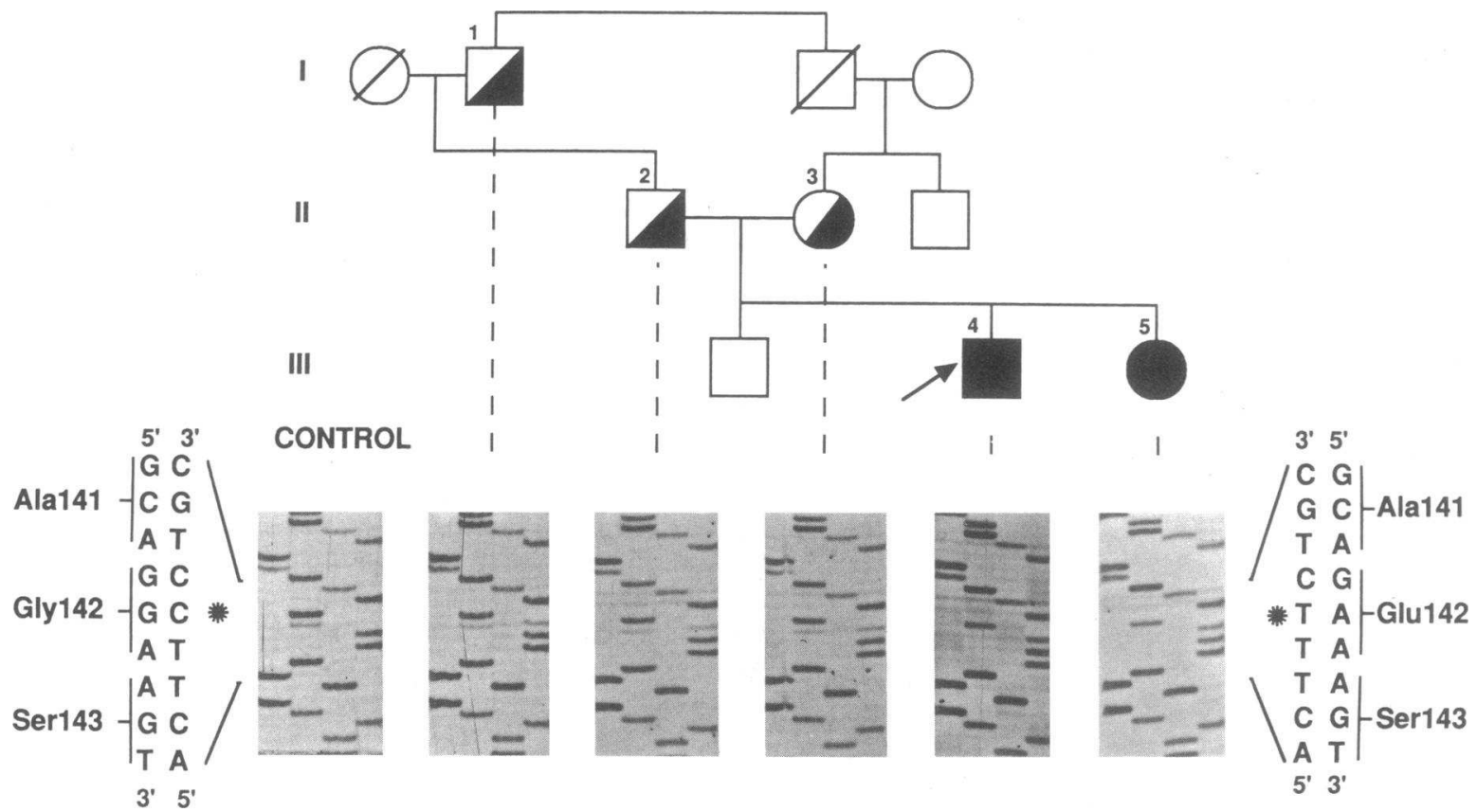

Figure 2. LPL-deficient kindred and DNA sequence of LPL exon 4 DNA. Pedigree analysis demonstrates consanguinity in the studied LPL-deficient family; the father and mother of the proband (II-2 and -3) are first cousins. Five members of the family were available for detailed study. Open symbols denote individuals not available; deceased individuals are indicated by symbols with slashes. Solid symbols indicate homozygous LPL-deficiency in the proband (III-4) and his sibling (III-5). Heterozygous subjects are indicated by half-solid symbols. The lower half of the figure shows direct DNA sequencing from the 416-bp fragment (Fig. 1) amplified from the indicated family members. DNA sequence analysis was performed with oligonucleotide primers FSE 4 and RSE 4 (Fig. 1) and analyzed by electrophoresis on $6 \%$ acrylamide/8 M urea sequencing gels. The order of lanes on the corresponding autoradiograms is A, C, G, and T, showing the DNA sequence derived from oligonucleotide primer FSE4. Because PCR amplifies both LPL alleles, heterozygotes show both a C (normal nucleotide) and a T (mutant nucleotide) in the middle of the codon for amino acid 142 . The two homozygous probands show only a $T$ at this position (asterisk). This missense mutation translates as a substitution of glutamic acid for glycine at position 142.

cient phenotype we have shown by in vitro expression studies that substitution of glutamic acid for glycine at amino acid residue 142 of human LPL produces an aberrant lipase which is catalytically inactive and is not efficiently secreted.

\section{Discussion}

We have analyzed nine exons comprising the complete coding region of the LPL gene in two subjects from a kindred with familial LPL deficiency. A single missense mutation was iden-

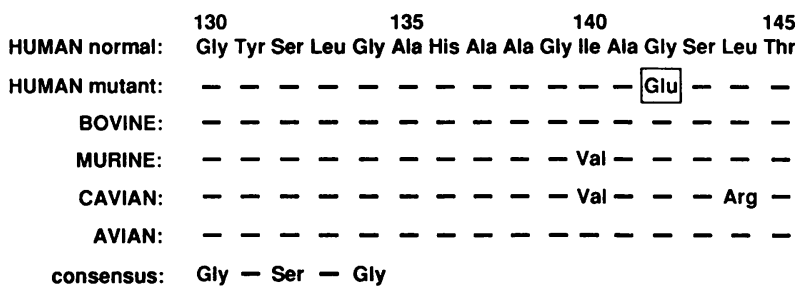

Figure 3. Region surrounding the nonconservative amino acid substitution (glycine-142 to glutamic acid) in four mammalian and one avian species. The normal human amino acid sequence for LPL (14) and the mutant with the substitution of glutamic acid for glycine (shown in box) are compared to the analogous sequences of bovine (21), murine (22), cavian (23), and avian (24) enzymes. The consensus sequence, glycine-x-serine-x-glycine, is encountered in all known lipases, some esterases, and a wide variety of serine proteases (29). Dashes indicate amino acid identity with the normal human sequence. tified in exon 4 of these two LPL-deficient patients. This mutation, a G-to-A transition at nucleotide 680 , results in the substitution of glutamic acid for glycine at position 142 (Fig. 2). Both
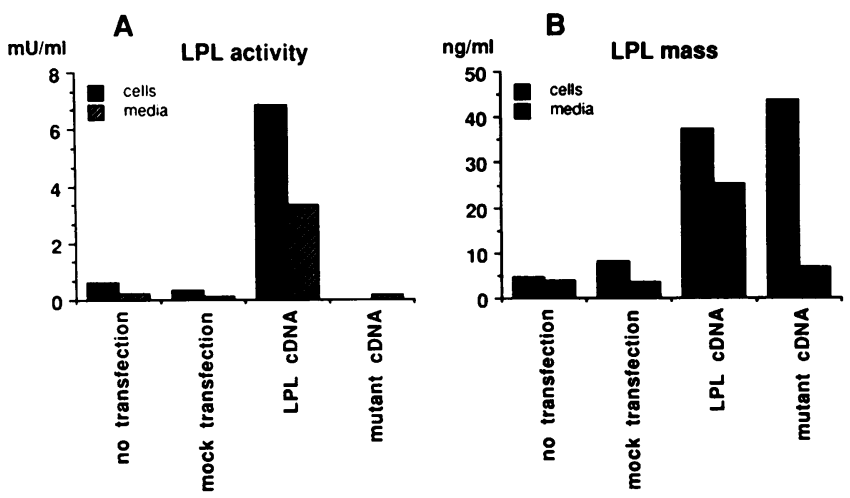

Figure 4. Effect of substitution of glutamic acid for glycine-142 on LPL expression in COS cells. COS cells were transfected with pSVL vector, denoted mock transfection, or with $\mathrm{pSVL}$ vector carrying the normal LPL cDNA (14), indicated as LPL cDNA, or with LPL cDNA containing the Glu-142 mutation, denoted mutant cDNA. No transfection refers to cells directly extracted and analyzed. $(A)$ LPL activity determination in $\mathrm{mU} / \mathrm{ml} ;(B)$ LPL mass in nanograms per milliliter as measured by an enzyme-linked immunosorbent assay (12). In both panels, LPL activity and mass were determined in cell homogenates (solid bars) and tissue culture medium (hatched bars). 
affected subjects were shown to be homozygotes for the mutation. As expected in diseases with autosomal recessive inheritance, both parents were heterozygotes for the G-to-A transition. Inheritance of the mutant allele could be traced to the paternal grandfather, who also demonstrated heterozygosity (Fig. 2).

Analysis of evolutionary relationships among different lipase genes shows that LPL is a highly conserved protein (26). In particular, the amino acid sequence surrounding glycine-142 is highly homologous in the several mammals whose LPL sequences are known (Fig. 3); glycine is the only residue utilized at the analogous position in these species. The reason for this high local sequence conservation perhaps derives from its proximity to the catalytic center of the enzyme. LPL serine-132 has been proposed as the catalytic serine on the basis of sequence homologies with a variety of serine esterases (44). This is supported by two recent experiments. First, human pancreatic lipase was recently crystallized and the three-dimensional structure shows serine-152 (analogous to human LPL serine-132) to be part of an aspartate/histidine/serine triad proposed to be essential for catalysis (45). Second, conservative amino acid substitution at the analogous residue in rat hepatic lipase (serine-147) dramatically reduces catalytic activity (44). Thus, the mutation identified in this kindred which substitutes a large, negatively charged glutamic acid in place of a small, neutral glycine residue within 10 amino acids of the proposed active site may be expected to disrupt enzymatic function.

The functional consequences of the detected mutation were confirmed utilizing site-directed mutagenesis to introduce the codon-142 mutation in the normal LPL cDNA. Expression studies indicated that mammalian cells transfected with the LPL mutant produced normal amounts of enzyme mass. The mutated LPL was not catalytically competent, nor was it efficiently released into the culture media. These results strongly suggest that the glutamic acid for glycine substitution at position 142 has a major adverse effect on the tertiary structure of the LPL molecule leading to a functionally deficient protein. Thus, the properties of the expressed mutant LPL were found to be consistent with the LPL-deficient phenotype observed in the proband.

LPL gene aberrations may be due to gross alterations or to specific point mutations. Recently, DNA analyses employing Southern hybridization indicated that gross alterations in the LPL gene in the form of insertion/deletion-type changes and duplication events were responsible for primary LPL deficiency in a significant number of type I hyperlipoproteinemic subjects $(31,32)$. LPL deficiency may also arise from mutations resulting in minor changes in enzyme structure that affect various properties, such as enzymatic half-life, substrate affinity, interaction with heparan sulphate or with the cofactor apolipoprotein C-II. The mutation described in this report points to a single base change at amino acid 142 , in very close proximity to the putative catalytically active site serine 132 . The recent mutational analysis of two additional pedigrees has shown effects of point mutations in other regions of the LPL molecule $(33,34)$. Sequence analysis of a kindred from Bethesda has revealed a single amino acid substitution of Ala for Thr at position 176 , leading to an inactive enzyme with reduced binding to heparin (33). A large family of Northern European ancestry was found to be LPL-deficient due to an amino acid substitution of Gly-188 to Glu, likewise resulting in a catalytically inactive protein with a lower affinity for heparin (34).
Thus, the mutation described in this report as well as the ones detected at different locations along the molecule $(33,34)$ suggest that LPL is very sensitive to single amino acid exchanges, frequently resulting in loss of enzymatic activity. Identification of additional naturally occuring mutants in other chylomicronemic individuals and the use of site-directed mutagenesis to systematically alter the LPL molecule will help to analyze the molecular properties of LPL and further our knowledge of their influence on triglyceride metabolism.

In addition to homozygous LPL-deficient subjects, the much larger population of heterozygotes carrying various LPL mutations may also be clinically affected. Although not evident in this kindred, some heterozygous LPL-deficient subjects have recently been shown to have familial combined hyperlipidemia $(13,46)$ which manifests itself as hypertriglyceridemia, hypercholesterolemia, or a combination of both. This condition is associated with premature atherosclerosis (47-49). Thus, heterozygous LPL-deficient patients in which mutations in the LPL gene may affect normal enzymatic function appear to form a subset of familial combined hyperlipidemia. The PCR technique in conjunction with direct DNA sequence analysis utilized in this study will undoubtedly facilitate the characterization of the structural variants of LPL. These variants will further aid in characterizing the possible role of LPL mutations in type I hyperlipoproteinemia, familial combined hyperlipidemia, and related disorders of lipid metabolism.

\section{Acknowledgments}

We are indebted to Dr. Jerome I. Rotter for lymphoblastoid cell lines of patients; and to Drs. Neil Kaplowitz, Andrew Stolz, Mark Doolittle, and Karen Reue for critically reading this manuscript.

This work was supported by grants HL 28481 and HL 14237 from the National Institutes of Health, the Veterans Administration, and the American Heart Association, Greater Los Angeles Affliate (492-IG 15). Dr. Ameis was supported in part by the Deutsche Forschungsgemeinschaft (Am 65/2-1), and Dr. Kobayashi was supported in part by Mochida funds (Japan).

\section{References}

1. Brunzell, J. D. 1989. Familial lipoprotein lipase deficiency and other causes of the chylomicronemia syndrome. In The Metabolic Basis of Inherited Disease. C. R. Scriver, A. L. Beaudet, W. S. Sly, and D. Valle, editors. McGraw-Hill Book Co., New York. 1165-1180.

2. Havel, R. J., and R. S. Gordon, Jr. 1960. Idiopathic hyperlipemia: metabolic studies in an affected family. J. Clin. Invest. 39:1777-1790.

3. Breckenridge, W. C., J. A. Little, G. Steiner, A. Chow, and M. Poapst. 1978 Hypertriglyceridemia associated with deficiency of apolipoprotein C-II. N. Engl. J. Med. 298:1265-1273.

4. Brunzell, J. D., N. E. Miller, P. Alaupovic, R. J. St. Hilaire, C. S. Wang, D. L. Sarson, S. R. Bloom, and B. Lewis. 1983. Familial chylomicronemia due to a circulating inhibitor of lipoprotein lipase activity. J. Lipid Res. 24:12-19.

5. Kihara, S., Y. Matsuzawa, M. Kubo, S. Nozaki, T. Funahashi, S. Yamashita, N. Sho, and S. Tarui. 1989. Autoimmune hyperchylomicronemia. N. Engl. J. Med. 320:1255-1259.

6. Eckel, R. H. 1989. Lipoprotein lipase: a multifunctional enzyme relevant to common metabolic diseases. N. Engl. J. Med. 320:1060-1068.

7. Garfinkel, A. S., and M. C. Schotz. 1987. Lipoprotein lipase. In Plasma Lipoproteins. A. M. Gotto, Jr., editor. Elsevier Science Publishers, New York. 335-357.

8. Olivecrona, T., and G. Bengtsson-Olivecrona. 1987. Lipoprotein lipase from milk: the model enzyme in lipoprotein lipase research. In Lipoprotein Lipase. J. Borensztajn, editor. Evener, Chicago. 15-58.

9. Cheng, C.-F., G. M. Oosta, A. Bensadoun, and R. D. Rosenberg. 1981. Binding of lipoprotein lipase to endothelial cells in culture. J. Biol. Chem. 256:12893-12898. 
10. Nilsson-Ehle, P., and M. C. Schotz. 1976. A stable, radioactive substrate emulsion for assay of lipoprotein lipase. J. Lipid Res. 17:536-541.

11. Greten, H., R. Degrella, G. Klose, W. Rascher, J. L. de Gennes, and E Gjone. 1976. Measurement of two plasma triglyceride lipases by an immunochemical method: studies in patients with hypertriglyceridemia. J. Lipid Res 17:203-210.

12. Goers, J. W. F., M. E. Pedersen, P. A. Kern, J. Ong, and M. C. Schotz 1987. An enzyme-linked immunoassay for lipoprotein lipase. Anal. Biochem. 166:27-35.

13. Babirak, S. P., P.-H. Iverius, W. Y. Fujimoto, and J. D. Brunzell. 1989. The detection and characterization of the heterozygote state for lipoprotein lipase deficiency. Arteriosclerosis. 9:326-334.

14. Wion, K. L., T. G. Kirchgessner, A. J. Lusis, M. C. Schotz, and R. M. Lawn. 1987. Human lipoprotein lipase complementary DNA sequence. Science (Wash. DC). 235:1638-1641.

15. Sparkes, R. S., S. Zollman, I. Klisak, T. G. Kirchgessner, M. C. Komaromy, T. Mohandas, M. C. Schotz, and A. J. Lusis. 1987. Human genes involved in lipolysis of plasma lipoproteins: mapping of loci for lipoprotein lipase to 8 p22 and hepatic lipase to 15q21. Genomics. 1:138-144.

16. Deeb, S. S., and R. Peng. 1989. Structure of the human lipoprotein lipase gene. Biochemistry. 28:4131-4135.

17. Kirchgessner, T. G., J.-C. Chuat, C. Heinzmann, J. Etienne, S. Guilhot, K Svenson, D. Ameis, C. Pilon, L. d'Auriol, A. Andalibi, M. C. Schotz, F. Galibert, and A. J. Lusis. 1989. Organization of the human lipoprotein lipase gene and evolution of the lipase gene family. Proc. Natl. Acad. Sci. USA. 86:9647-9651.

18. Ameis, D., G. Stahnke, J. Kobayashi, M. Bücher, G. Lee, J. McLean, M. C. Schotz, and H. Will. 1990. Isolation and characterization of the human hepatic lipase gene. J. Biol. Chem. 265:6552-6555.

19. Mickel, F. S., F. Weidenbach, B. Swarowsky, K. S. LaForge, and G. A. Scheele. 1989. Structure of the canine pancreatic lipase. J. Biol. Chem 264:12895-12901.

20. Komaromy, M. C., and M. C. Schotz. 1987. Cloning of rat hepatic lipase cDNA: evidence for a lipase gene family. Proc. Natl. Acad. Sci. USA. 84:15261530.

21. Senda, M., K. Oka, W. V. Brown, P. K Qasba and Y. Furuichi. 1987. Molecular cloning and sequence of a cDNA coding for bovine lipoprotein lipase. Proc. Natl. Acad. Sci. USA. 84:4369-4373.

22. Kirchgessner, T. G., K. L. Svenson, A. J. Lusis, and M. C. Schotz. 1987 The sequence of cDNA encoding lipoprotein lipase: a member of a lipase gene family. J. Biol. Chem. 262:8463-8466.

23. Enerbäck, S., H. Semb, G. Bengtsson-Olivecrona, P. Carlsson, M.-L. Hermansson, T. Olivecrona, and G. Bjursell. 1987. Molecular cloning and sequence analysis of cDNA encoding lipoprotein lipase of guinea pig. Gene (Amst.). 58:112.

24. Cooper, D. A., J. C. Stein, P. J. Strieleman, and A. Bensadoun. 1989. Avian adipose lipoprotein lipase: cDNA sequence and reciprocal regulation of mRNA levels in adipose and heart. Biochim. Biophys. Acta. 1008:92-101.

25. Stahnke, G., R. Sprengel, J. Augustin, and H. Will. 1987. Human hepatic triglyceride lipase: cDNA cloning, amino acid sequence and expression in a cultured cell line. Differentiation. 35:45-52.

26. Datta, S., C.-C. Luo, W.-H. Li, P. VanTuinen, D. H Ledbetter, M. A. Brown, S.-H. Chen, S.-w. Liu, and L. Chan. 1988. Human hepatic lipase. Cloned cDNA sequence, restriction fragment length polymorphism, chromosomal localization, and evolutionary relationships with lipoprotein lipase and pancreatic lipase. J. Biol. Chem. 263:1107-1110.

27. Martin, G. A., S. J. Busch, G. D. Meredith, A. D. Cardin, D. T. Blankenship, S. J. T. Mao, A. E. Rechtin, C. W. Woods, M. M. Racke, M. P. Schafer, M. C. Fitzgerald, D. M. Burke, M. A. Flanagan, and R. L. Jackson. 1988. Isolation and cDNA sequence of human postheparin plasma hepatic triglyceride lipase. J. Biol. Chem. 263:10907-10914.

28. Kerfelec, B., K. S. LaForge, A. Puigserver, and G. Scheele. 1986. Primary structures of canine pancreatic lipase and phospholipase A2 messenger RNAs. Pancreas. 1:430-437.
29. Brenner, S. 1988. The molecular evolution of genes and proteins: a tale of two serines. Nature (Lond.). 334:528-530.

30. Bownes, M., A. Shirras, M. Blair, J. Collins, and A. Coulson. 1988. Evidence that insect embryogenesis is regulated by ecdysteroids released from yolk proteins. Proc. Natl. Acad. Sci. USA. 85:1554-1557.

31. Langlois, S., S. Deeb, J. D. Brunzell, J. J. Kastelein, and M. R. Hayden. 1989. A major insertion accounts for a significant proportion of mutations underlying human lipoprotein lipase deficiency. Proc. Natl. Acad. Sci. USA. 86:948952.

32. Devlin, R. H., S. Deeb, J. Brunzell, and M. R. Hayden. 1990. Partial gene duplication involving exon-Alu interchange results in lipoprotein lipase deficiency. Am. J. Hum. Genet. 46:112-119.

33. Beg, O. U., M. S. Meng, S. I. Skarlatos, L. Previato, J. D. Brunzell, H. B.

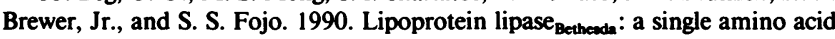
substitution (Ala-176 $\rightarrow \mathrm{Thr}$ ) leads to abnormal heparin binding and loss of enzymic activity. Proc. Natl. Acad. Sci. USA. 87:3474-3478.

34. Emi, M., D. E. Wilson, P.-H. Iverius, L. Wu, A. Hata, R. Hegele, R. R Williams, and J.-M. Lalouel. 1990. Missence mutation (Gly $\rightarrow$ Glu $^{188}$ ) of human lipoprotein lipase imparting functional deficiency. J. Biol. Chem. 265:59105916.

35. Pagnan, A., R. J. Havel, J. P. Kane, and L. Kotite. 1977. Characterization of human very low density lipoproteins containing two electrophoretic populations: double pre-beta lipoproteinemia and primary dysbetalipoproteinemia. $J$. Lipid Res. 18:613-622.

36. Menzel, H.-J., J. P. Kane, M. J. Malloy, and R. J. Havel. 1986. A variant primary structure of apolipoprotein C-II in individuals of african descent. J. Clin. Invest. 77:595-601.

37. Menezes, J., W. Leibold, and G. Klein. 1975. Biological differences between Epstein-Barr virus (EBV) strains with regard to lymphocyte transforming ability, superinfection and antigen induction. Exp. Cell Res. 92:478-484.

38. Sugden, B., and W. Mark. 1977. Clonal transformation of adult human leukocytes by Epstein-Barr virus. J. Virol. 23:503-508.

39. Saiki, R. K., D. H. Gelfand, S. Stoffel, S. J. Scharf, R. Higuchi, G. T. Horn K. B. Mullis, and H. A. Erlich. 1988. Primer-directed enzymatic amplification of DNA with a thermostable DNA polymerase. Science (Wash. DC) 239:487-491.

40. Innis, M. A., K. B. Myambo, D. H. Gelfand, and M. A. D. Brow. 1988. DNA sequencing with Thermus aquaticus DNA polymerase and direct sequencing of polymerase chain reaction-amplified DNA. Proc. Natl. Acad. Sci. USA. 85:9436-9440.

41. Sambrook, J., E. F. Fritsch, and T. Maniatis. 1989. Molecular Cloning: A Laboratory Manual. Cold Spring Harbor Laboratory, Cold Spring Harbor, NY.

42. Sanger, F., S. Nicklen, and A. R. Coulson. 1977. DNA sequencing with chain-terminating inhibitors. Proc. Natl. Acad. Sci. USA. 74:5463-5467.

43. Boberg, J., and L. A. Carlson. 1964. Determination of heparin-induced lipoprotein lipase activity in human plasma. Clin. Chim. Acta. 10:420-427.

44. Davis, R. C., G. Stahnke, H. Wong, M. H. Doolittle, D. Ameis, H. Will, and M. C. Schotz. 1990. Hepatic lipase: site-directed mutagenesis of a serine residue important for catalytic activity. J. Biol. Chem. 265:6291-6295.

45. Winkler, F. K., A. D'Arcy, and W. Hunziker. 1990. Structure of human pancreatic lipase. Nature (Lond.). 343:771-774.

46. Brunzell, J. D., and M. A. Austin. 1989. Plasma triglyceride levels and coronary disease. $N$. Engl. J. Med. 320:1273-1275.

47. Goldstein, J. L., H. G. Schrott, W. R. Hazzard, E. L. Bierman, and A. G. Motulsky. 1973. Hyperlipidemia in coronary heart disease. II. Genetic analysis of lipid levels in 176 families and delineation of a new inherited disorder, combined hyperlipidemia. J. Clin. Invest. 52:1544-1568

48. Brunzell, J. D., J. J. Albers, A. Chait, S. M. Grundy, E. Groszek, and G. B. McDonald. 1983. Plasma lipoproteins in familial combined hyperlipidemia and monogenic familial hypertriglyceridemia. J. Lipid Res. 24:147-155.

49. Kane, J. P., and R. J. Havel. 1989. Disorders of the biogenesis and secretion of lipoproteins containing the B apolipoproteins. In The Metabolic Basis of Inherited Disease. C. R. Scriver, A. L. Beaudet, W. S. Sly, and D. Valle, editors. McGraw-Hill Book Co., New York. 1139-1164. 